\title{
The influence of age in decision-making of patients with HCC
}

\author{
S Puleo ${ }^{*}$, L Nigro, T R Portale, A Pesce, M A Trovato \\ From de Senectute: Age and Health Forum \\ Catanzaro, Italy. 5-7 December 2009
}

\section{Background}

Hepatocellular carcinoma (HCC) is usually associated with liver cirrhosis and is the principal cause of death among patients with cirrhosis [1]. Apart from liver transplantation that may cure both conditions, treatment of HCC and cirrhosis is complex because of the need to be oncologically radical but simultaneously conservative. Hepatectomy is considered an invasive approach and has a marginal role in the treatment of $\mathrm{HCC}[2,3]$. A retrospective analysis of 62 patients affected by HCC observed from 2000 to 2008 was performed. The treatment choice was compared with the treatment schedule proposed by BCLC. Among these patients, 27 (43.5\%) were over 70 years old; of these 16 were men and 11 women. Regarding Child classification 18 patients (66.6\%) were CHILD A, 8 (29.6 \%) CHILD B and $1(3.8 \%)$ CHILD C. We evaluated the influence of age in our clinical behaviour, exploiting the BCLC guidelines. In $9(33.3 \%)$ cases patients were treated according to BCLC algorithm but mainly with percutaneous ablation therapies, while in the remaining18 (66.7\%) cases there was an undertreatment in $15(83.3 \%)$ patients and an overtreatment in $3(16.7 \%)$. About the undertreatment cases we didn't perform hepatic resection or liver transplantation such as BCLC suggests mainly because of advanced age ( $>70$ years old). With regard to the overtreatment we performed 3 transarterial embolizations rather than sorafenib or symptomatic therapy because the general conditions of patients were fairly good.

\section{Conclusions}

BCLC algorithm is considered the most important staging system for patients with HCC. This classification uses variables related to tumour stage, liver functional status, physical status but not the age of patients. This concept is very important because decision-making of

$$
\text { Department of Surgery, University of Catania, AOU Policlinico-Vittorio }
$$$$
\text { Emanuele, Catania, Italy }
$$

hepatic surgeons often depends on age of patient. Although there are many papers in scientific literature that confirm the safety of surgery in elderly patients, it is also true that the risk of local and general complications is very high. The presence of comorbidity and refusal of patients to undergo surgery or liver transplantation are often the main reason for our clinical behaviour. In the management of these patients we have to consider the age and risk-benefit ratio.

Published: 19 May 2010

\section{References}

1. Fattovich G, Giustina G, Degos F, et al: Morbidity and mortality in compensated cirrhosis type C: a retrospective follow-up study of 384 patients. Gastroenterology 1997, 112(2):463-472.

2. Bruix J, Llovet JM: Prognostic prediction and treatment strategy in hepatocellular carcinoma. Hepatology 2002, 35(3):519-524.

3. Llovet JM, Fuster J, Bruix J: Barcelona-Clinic Liver Cancer Group. The Barcelona approach: diagnosis, staging, and treatment of hepatocellular carcinoma. Liver Transpl 2004, 10(2)(Suppl 1):S115-S120.

doi:10.1186/1471-2318-10-S1-A26

Cite this article as: Puleo et al.: The influence of age in decision-making of patients with HCC. BMC Geriatrics 2010 10(Suppl 1):A26.

Submit your next manuscript to BioMed Central and take full advantage of:

- Convenient online submission

- Thorough peer review

- No space constraints or color figure charges

- Immediate publication on acceptance

- Inclusion in PubMed, CAS, Scopus and Google Scholar

- Research which is freely available for redistribution

Submit your manuscript at www.biomedcentral.com/submit
Ciomed Central 